DOI: $10.34185 / 1991-7848.2018 .01 .10$

УДК 682.788 .36

Ю.С. Рудь, В.Г. Кучер, В.Ю. Белоножко

\title{
НОВОЕ НАПРАВЛЕНИЕ В РАЗРАБОТКЕ МЕТОДОВ И СРЕДСТВ ФОРМИРОВАНИЯ СЛОЯ ШИХТЫ НА АГЛОМЕРАЦИОННОЙ МАШИНЕ
}

Барабанные питатели, которые применяются на агломерационных машинах для загрузки шихты на колосниковую решетку, не обеспечивают получение рациональной сегрегации шихты по высоте слоя. Попытки снизить негативное влияние полученной при этом сегрегации материала путем укладки на решетку агломерационных машин двух или больше слоев шихты не дали ожидаемых результатов. Вопрос достижения заданного распределения материала шихты по крупности по высоте слоя за счет управляемой сегрегации загружаемого материала по-прежнему является актуальной научной и практической задачей. Выполнен анализ эффективности известных методов и средств формирования слоя шихты при ее укладке на колосниковую решетку агломерационных машин. Показано, что одним из наиболее перспективных направлений формирования слоя шихты является управление процессом сегрегации гранулированной шихты по высоте слоя в зависимости от ее крупности и содержания в ней топлива. Одним из видов технологического оборудования для разделения шихты по фракционному составу могут быть линейные разделители. Реализация предложенных технологических схем с использованием линейных разделителей обеспечивает заданное распределение фракций гранулированной шихты по высоте слоя с постепенным ростом содержания топлива в верхних слоях шихты, что позволяет увеличить производительность агломерационных машин и улучшить качество выпускаемого агломерата.

Ключевые слова: агломерационная машина, агломерат, сегрегация шихты, линейный разделитель, производительность, качество агломерата.

\section{Актуальность исследований}

Процесс агломерации тонкоизмельченных железных руд имеет комплексный характер, в соответствии с которым технологическое оборудование агломерационной фабрики можно разделить на три последовательно соединенных технологических подсистемы. Эти подсистемы реализуют следующие технологические процессы: подготовку железорудного сырья (шихты) к агломерации; агломерацию шихты; разгрузку и дробление полученного агломерата с выделением из него возврата - мелкой некондиционной фракции 0-5 мм. Технологическое оборудование первой подсистемы содержит устройства для дозирования и смешивания компонентов шихты, а также для их грануляции и транспортирования гранулированной шихты на агломерационную машину. Агломерация шихты осуществляется на агломерационных машинах, которые содержат устройства для загрузки шихты на подвижные тележки с колосниковой решеткой, зажигательный горн, вакуум-камеры и газопроводы для отвода газо-воздушной смеси из вакуум-камер. Агломерация окомкованной шихты обеспечивает образование относительно крупных пористых кусков - агломерата из мелкой руды и других материалов. Это осуществляется за счет слипания минеральных частиц между собой вследствие затвердевания легкосплавных компонентов после их нагревания ниже температуры плавления. Термическая обработка агломерата включает процесс его охлаждения. Полученный продукт - агломерат разгружается с подвижных тележек машины и подвергается дроблению и сортировке по крупности.

Промышленностью освоен выпуск нескольких типоразмеров агломерационных машин АК-50, АКМ-75, АКМ-85/160, АКМ-105, АКМ-312, обеспечивающих производительность соответственно 40-90, 75-150, 145-160 и 450-540 т/ч. Большинство из них в процессе эксплуатации подвергались модернизации - удлинялась рабочая часть машины, при этом ее дополнительная часть служила для охлаждения агломерата; на некоторых машинах

() Рудь Ю.С., Кучер В.Г., Белоножко В.Ю., 2018 
устанавливались линейные охладители. Однако составные части агломерационной машины при этом оставались неизменными. В Украине получили распространение агломерационные машины типа АКМ-75. На этих машинах отрабатывалась рациональная технология подготовки шихты к спеканию и ее загрузки на колосниковую решетку тележек, так как эти процессы определяет дальнейший ход процесса агломерации. Основными агрегатами, которые обеспечивают процесс подготовки шихты к спеканию, являются барабанные смесителиокомкователи. Гранулированная шихта с барабанных смесителей-окомкователей подается на челноковые распределители, которыми шихта загружается в бункер барабанного питателя агломерационной машины. Затем при помощи загрузочного лотка шихта укладывается на колосниковую решетку. Технологический блок оборудования, предназначенного для загрузки сырья, обеспечивает получение заданной высоты слоя шихты на колосниковой решетке и качество ее укладки. Сложность задачи загрузки сырья на колосниковую решетку состоит в том, что этот процесс связан с неуправляемым явлением сегрегации гранулированных частиц шихты, вызывающим нерациональное распределение фракционного состава шихты по высоте слоя.

\section{Проблема и ее связь с научными и практическими задачами}

В проектных решениях агломерационных фабрик Украины предусматривалось оборудование для выделения дробленого агломерата фракции 25-12 мм, его транспортировки и загрузки отдельным питателем на колосниковую решетку для использования в качестве нижнего слоя шихты - постели. Реализация проектных схем загрузки была связана со значительными усложнениями структуры агломерационных фабрик, что привело к постепенному отказу фабрик от технологического участка по выделению фракций крупностью 25-12 мм. Это решение в значительной степени ухудшило условия эксплуатации колосниковых решеток, резко снизило сроки службы колосников, работающих при высоких температурах в зоне спекания шихты. Кроме того, процессы сегрегации, наблюдаемые при загрузке шихты непосредственно на колосниковую решетку (а не на слой постели), приводят к нерациональному распределению шихты по крупности по высоте слоя. Крупные фракции концентрируются в верхних и средних слоях шихты, а мелкие - в нижних. Такое распределение крупных и мелких фракций шихты по высоте слоя приводит к соответствующему распределению топлива, количество которого уменьшается с увеличением крупности гранул шихты. Как показали многочисленные исследования, барабанные питатели, преимущественно применяемые на агломерационных машинах для загрузки шихты, являются простыми и надежными устройствами, однако они не обеспечивают рациональную сегрегацию шихты по высоте слоя. Попытки снизить негативное влияние сегрегации материала на колосниковой решетке путем укладки на колосниковую решетку агломерационных машин двух или больше слоев не дали положительных результатов из-за сложности их реализации, поэтому на большинстве агломерационных фабрик от таких схем отказались.

Таким образом, обеспечение заданного распределения крупности материала по высоте слоя шихты, уложенной на колосниковой решетке, за счет управляемой сегрегацией загружаемого материала по-прежнему является актуальной научной и практической задачей.

\section{Постановка задачи}

Цель работы - разработка новых методов и средств формирования слоя шихты на колосниковой решетке агломерационной машины, обеспечивающих заданное распределение гранул материала и содержания в нем топлива по высоте слоя шихты. 


\section{Анализ последних исследований и публикаций}

Производительность агломерационной машины непрерывного действия можно определить по общепринятой формуле

$Q=60 K B H \gamma v, \quad$ т/ч,

где $K$ - коэффициент выхода годного агломерата из шихты, \%; $B$ - полезная длина подвижной тележки агломерационной машины, м; $H$ - высота слоя шихты на колосниковой решетке подвижной тележки, м; $\gamma$ - насыпная масса шихты, т/м³ $; v$ - скорость движения подвижных тележек машины, м/мин.

Скорость движения подвижных тележек $v$ зависит от вертикальной скорости спекания $C$ (м/мин), высоты спекаемого слоя шихты $H$ (м), полезной длины рабочей части колосниковой решетки $l$ (м) и выражается зависимостью

$v=l C / H, \mathrm{~m} / \mathrm{мин.}$

Подставив значение скорости $v$ из выражения (2) в формулу (1) получим формулу для определения производительности машины

$$
Q=60 K S \gamma C, \quad \mathrm{~T} / \mathrm{ч},
$$

где $S=B l, \mathrm{M}^{2}$ - полезная площадь колосниковой решетки агломерационной машины.

Анализ формулы (3) подтверждает мнение автора работы [1], что повышение производительности агломерационных машин может быть достигнуто за счет увеличения вертикальной скорости спекания и величины выхода кондиционного агломерата. Вегман Е.Р. [2] считает, что при постоянном вакууме производительность агломерационной машины практически полностью определяется газопроницаемостью слоя шихты, лимитируя тем самым количество просасываемого через слой воздуха. Между газопроницаемостью слоя шихты на колосниковой решетке и производительностью машины наблюдается линейная зависимость, поэтому необходимо готовить шихту к спеканию по технологии, обеспечивающей в данных условиях максимально возможную газопроницаемость спекаемого слоя. Мартыненко В.А. и Кухарь А.С. в работе [3] утверждают, что повышение газопроницаемости спекаемого слоя может быть достигнуто за счет обеспечения необходимой степени ее сегрегации при загрузке на колосниковую решетку подвижных тележек машины. Эту задачу предлагается решить за счет изменения конструкции загрузочного лотка. Авторы работы [4] считают, что современное агломерационное производство достаточно совершенно, однако его потенциальные возможности далеко не исчерпаны. В настоящее время предлагается сосредоточить внимание на разработке типовой конструкции загрузочного лотка, позволяющего достичь максимального эффекта сегрегации шихты с рациональным распределением фракционного состава шихты по высоте слоя. Базилевич С.В. [5] считает, что газопроницаемость спекаемого слоя можно существенно повысить, если обеспечить заданную сегрегацию частиц по его высоте. Результаты экспериментальных исследований, проведенных авторами роботы [6, 7], подтвердили, что максимальную газопроницаемость слоя обеспечивает установка загрузочного лотка барабанного питателя шихты под углом, равным или близким к углу естественного откоса окомкованной шихты.

В работах [8, 9] показано, что прочностные характеристики агломерата во многом зависят от распределения топлива по высоте слоя. При использовании для загрузки шихты на подвижные тележки агломерационных машин барабанных питателей происходит ее расслоение по фракциям, когда более крупные частицы скатываются к основанию слоя, а мелкие сосредоточены в его верхней части. Как отмечает Ефименко Г.Г. [10] в агломерационной шихте около 83\% топлива сосредотачивается во фракциях 0-3 мм, поэтому сегрегация шихты по гранулометрическому составу вызывает ее сегрегацию по содержанию топлива, что оказывает значительное влияние на тепловой режим спекания и, следовательно, на прочность агломерата. Начальный период спекания характеризуется недостатком теплоты, 
вследствие чего верхняя часть слоя агломерата является наименее прочной. Авторы работы [11] считают, что одним из преимуществ загрузки шихты с помощью барабанных питателей является образование постели из крупных гранул шихты. Однако эти утверждения не подтверждаются практическими наблюдениями, а постель, образованная при загрузке шихты, значительно уступает по своим характеристикам постели из агломерата крупностью 25-12 мм, от которой отказались на агломерационных фабриках.

\section{Изложение материала и результаты}

Для обеспечения высокого качества агломерата температура зоны горения топлива шихты, уложенной на колосниковую решетку, должна быть постоянной в течение всего процесса спекания (линия $A_{P} B C_{P}$ графика, приведенного на рис. 1). Однако фактическое распределение температуры зоны горения шихты отличатся от рационального распределения (ломаная линия $A_{\Phi} B C_{\Phi}$ графика рис. 1). В верхней части загруженного на колосниковую решетку слоя шихты наблюдается дефицит тепла (выражается площадью треугольника $A_{\Phi} B A_{P}$ графика рис. 1) [12]. Из-за недостатка тепла спекание шихты протекает в неблагоприятных условиях, и верхняя часть слоя агломерата имеет пониженную прочность. При движении зоны горения топлива шихты сверху вниз за счет тепла, поступающего из верхних слоев агломерата, приход тепла в нижние слои постепенно возрастает. Вблизи колосниковой решетки в шихте наблюдается избыток тепла (выражается площадью треугольника $C_{\Phi} B C_{P}$ графика рис. 1 ), что приводит к оплавлению агломерата и снижению его восстановимости. Для выравнивания температуры спекания по высоте слоя необходимо увеличить приход тепла в верхние слои шихты и ограничить его поступление в нижние слои.

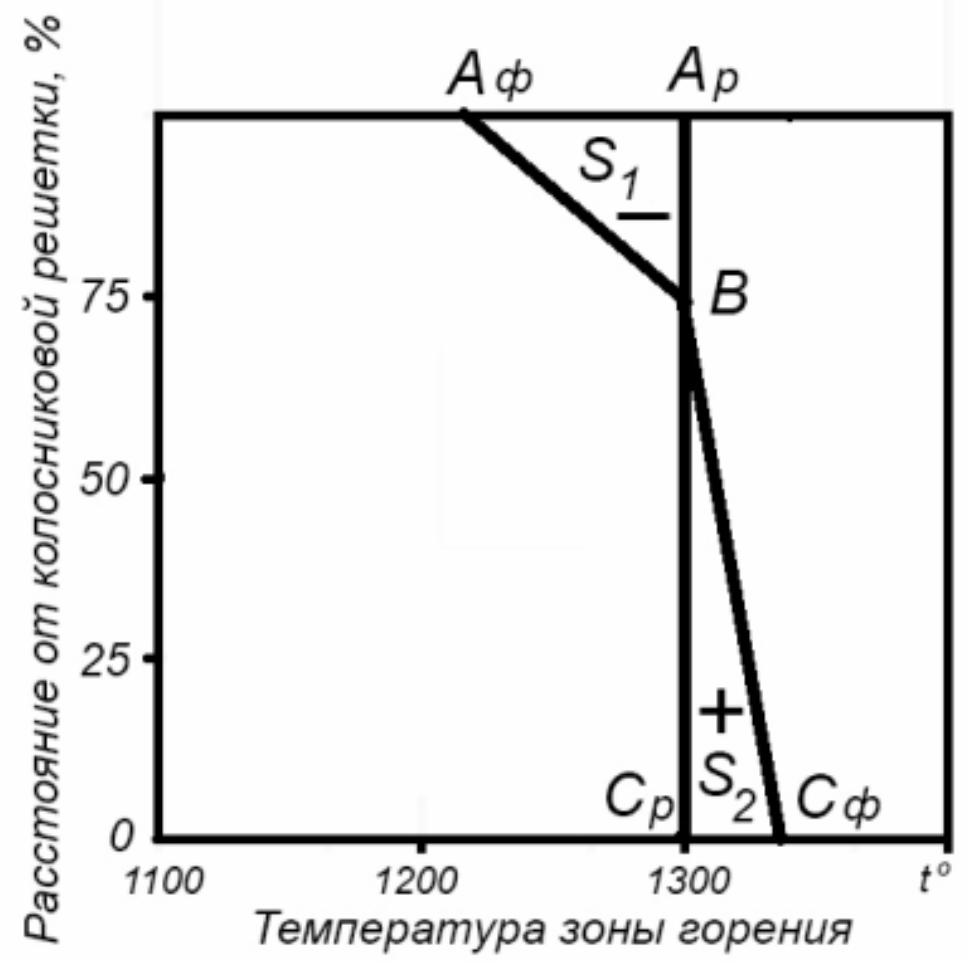

Рисунок 1 - Распределение температуры в зоне горения топлива при ее движении к колосниковой решетке:

$A_{P} B C_{P}$ - график распределения рациональной температуры;

$A_{\Phi} B C_{\Phi}$ - график фактического распределения температуры слоя шихты;

$S_{1}$ - площадь треугольника, где наблюдается дефицит тепла;

$S_{1}$ - площадь треугольника, где наблюдается избыток тепла 
Одно из решений данной задачи представляет собой использование многослойного (чаще рассматривается вариант двухслойного) спекания шихты, содержащей в разных слоях разную концентрацию углерода и имеющую разный фракционный состав. Так авторами данной статьи еще в 1982 г. предложена конструкция конвейерной агломерационной машины для спекания шихты, загруженной на колосниковую решетку двумя слоями [13]. В этой конструкции устраняется серьезный недостаток известных в то время конструкций агломерационных машин - обеспечивается снижение динамических нагрузок на привод за счет применения роликового питателя, расположенного в торце разделителя слоя, и ротора с радиальными зубьями, вращающегося от привода.

В 2016 г. авторами статьи предложен способ спекания шихты на агломерационных машинах двумя слоями заданной высоты с различным содержанием топлива, предусматривающий предварительную загрузку постели и дальнейшую двухслойную загрузку шихты [14]. При реализации способа спекания предварительно определяется график зависимости температуры зоны горения со средним содержанием топлива шихты (в нижнем и верхнем слоях) от расстояния зоны горения до колосниковой решетки (см. рис. 1). Высоту нижнего и верхнего слоев шихты выбирают пропорциональными отрезкам прямых от точки пересечения линий $A_{P} B C_{P}$ и $A_{\Phi} B C_{\Phi}$ (т. $B$ ). Среднее содержание топлива верхнего и нижнего слоев корректируется пропорционально площадям участков $S_{1}$ и $S_{2}$, которые образованы линиями рационального значения температуры горения и графиком фактической температуры горения шихты со средним содержанием топлива. Недостаток способа сложность его реализации, так как для этого требуется три опытных линии технологического оборудования, которые обеспечивают подготовку и подачу к агломерационной машине постели и двух видов шихты разного фракционного состава. Кроме того, при изменении состава шихты необходимо выполнять перерасчет содержания топлива в слоях. Однако экономия топлива и лучшие экологические показатели работы агломерационной машины оправдывают это усложнение.

Следует отметить важность выводов, сделанных на базе исследований эффективности работы агломерационной машины, реализующей способ двухслойного спекания шихты на агломерационной фабрике Ново-Липецкого металлургического завода [15]. Основное достоинство двухслойной загрузки шихты заключается в том, что предоставляется возможность управлять распределением топлива по высоте слоя с целью оптимизации температурно-топливного режима зажигания. K недостаткам двухслойной загрузки шихты следует отнести образование смешанной зоны спекания, которая зачастую сводит к минимуму эффект от раздельного дозирования топлива по слоям. Это происходит из-за скачкообразного изменения содержания топлива при переходе от верхнего к нижнему слою. Избыточное содержание топлива в верхнем слое приводит к образованию дополнительного тепла в середине слоя шихты. Другим недостатком двухслойной загрузки шихты является то, что под загрузкой занята большая часть полезной площади агломерационной машины. С учетом того, что газопроницаемость «двухслойного» слоя ниже газопроницаемости «однослойного» на 15$20 \%$, большинство агломерационных фабрик отказались от двухслойного спекания шихты.

Большой объём исследований по данной проблеме провели сотрудники Запорожской государственной инженерной академией [16]. В их работах показано, что одним из наиболее перспективных направлений повышения эффективности агломерационного процесса является управление процессом сегрегации окомкованной шихты в процессе ее загрузки на агломерационную решетку.

Кроме того, сложной проблемой, которая до сих пор не имеет технического решения, является создание работоспособного технологического оборудования для разделения окомкованной шихты на различные фракции. Применяемые грохота разной конструкции 
ввиду быстрой забивки просеивающей поверхности не могут быть рекомендованы для промышленного использования. Для разделения шихты по фракционному составу могут быть использованы линейные разделители, конструкция которых предложена авторами роботы [17]. Линейный разделитель представляет собой ленточный конвейер, установленный между питателем и окомкователем под углом $15-30^{0}$ (рис. 2).

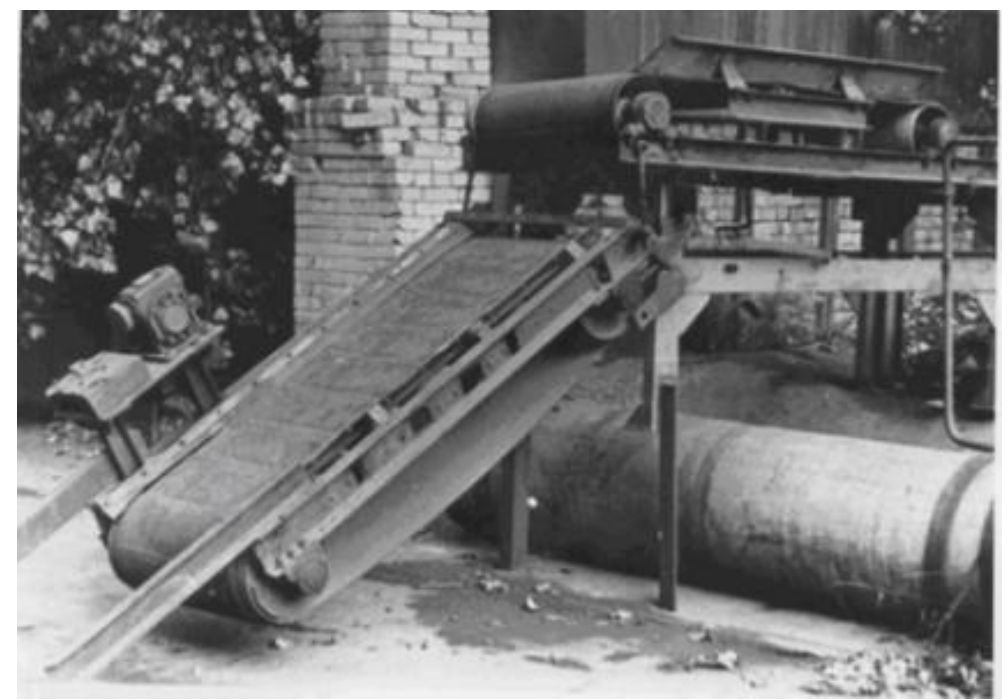

Рисунок 2 - Устройство для разделения агломерационной шихты на фракции

Верхний конец разделителя подвешен к раме шарнирно, а противоположный - соединен со штоком подъёмника. Технологическая схема участка для разделения шихты по фракционному составу с использованием линейного разделителя состоит из вибропитателя 1 , наклонного ленточного конвейера 2 и барабана-окомкователя 3 (рис. 3).

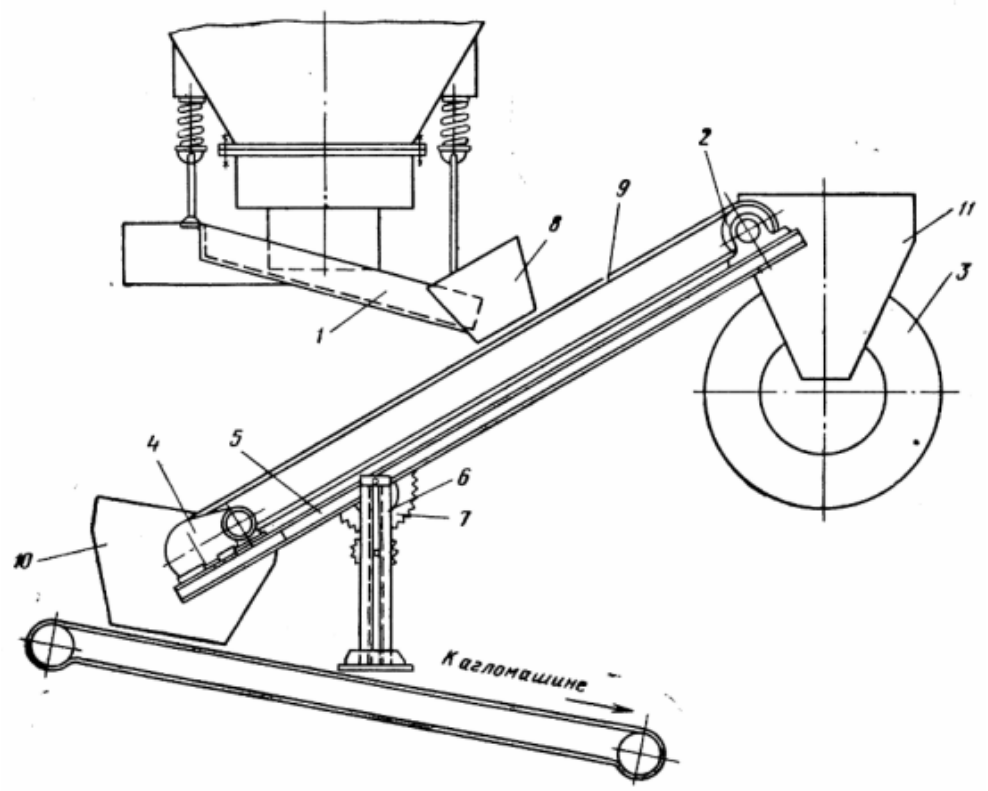

Рисунок 3 - Технологическая схема участка для разделения шихты по фракционному составу с линейным разделителем

Конвейер 2 имеет привод 4 с двигателем постоянного тока, позволяющим плавно регулировать скорость ленты в широком диапазоне. Верхний конец рамы 5 конвейера закреплен шарнирно, а нижний - соединен опорой 6 со штоком и при помощи поворотного механизма 7 может изменять угол наклона конвейера. Конвейер 2 устанавливают под таким углом, который обеспечивающим скатывание агломерационной шихты вниз. Для шихты 
агломерационной фабрики №2 НКгОК оптимальным углом наклона конвейера является угол $30^{0}$ и скорость ленты конвейера - $1 \mathrm{~m} /$ сек. Рассматриваемый линейный разделитель позволяет выделить до 15-20\% крупных фракций (+5 мм) от общей массы шихты и тем самым улучшить ее гранулометрический состав. Количество класса шихты 3-0 мм снижается на 25-30\%. В результате производительность машины повышается на 5-8\%, а износостойкость колосниковой решетки увеличивается вдвое благодаря использованию постели из крупных фракций шихты.

Промышленные испытания линейного разделителя по схеме рис. 3 показали недостаточную эффективность разделения шихты по фракциям. Крупные фракции в виде ноздреватых кусков возврата и частиц неправильной формы руды оставались в массе не окомкованной шихты. Для формирования постели использовались лишь те частицы, которые находились на ленте в верхних слоях шихты.

Авторами [18] предлагается реализовать трехслойную загрузку шихты заданного состава с использованием в технологической схеме двух линейных разделителей, барабанного питателя и загрузочного лотка (рис. 4).

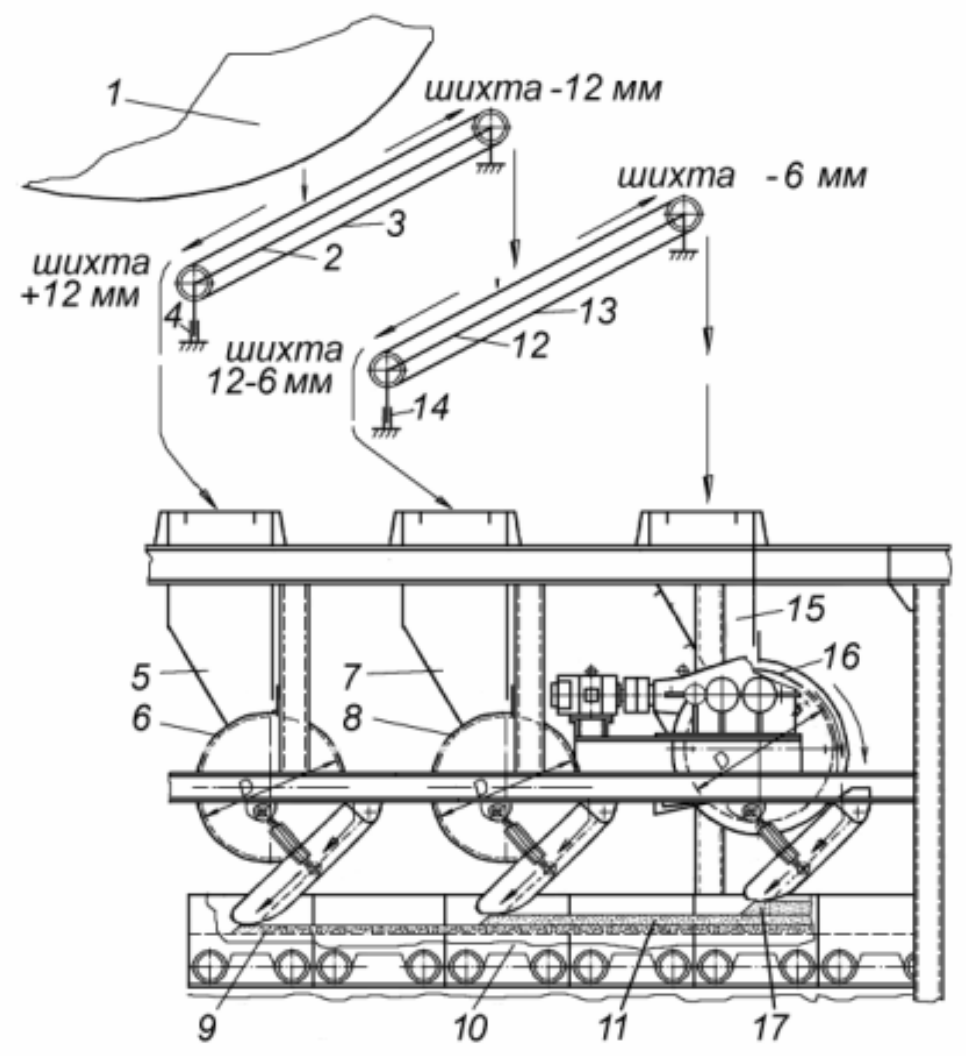

Рисунок 4 - Технологическая схема трехслойной загрузки шихты с использованием линейного разделителя

Линейные разделители обеспечивают разделение окомкованой шихты на три фракции. Фракция шихты крупностью +12 мм используется на колосниковой решетке в качестве постели, фракция шихты 12-6 мм используется для формирования среднего слоя шихты, а фракция шихты -6 мм - для формирования верхнего слоя шихты. Технологическая схема трехслойной загрузки шихты на колосниковую решетку агломерационной машины состоит из окомкователя 1 , наклонного ленточного конвейера 2 с рамой и лентой 3 , причем верхняя часть рамы закреплена шарнирно, а нижняя - соединена со штоком подъемника 4, загрузочного бункера постели 5, питателя 6, бункера шихты 7 с питателем 8. Колосниковая решетка агломерационной машины обозначена цифрой 9, слой постели - цифрой 10 , слой 
кондиционной шихты крупностью 12-6 мм - цифрой 11. Дополнительный наклонный конвейер 12 с лентой 13 и подъемником 14 подает шихту крупностью -6 мм в бункер 15. Отсюда обогащенная топливом шихта крупностью -6 мм питателем 16 подается на колосниковую решетку для создания верхнего слоя.

Использование технологической схемы с трехслойной загрузкой шихты на колосниковую решетку позволяет обеспечить повышение производительности агломерационной машины и улучшение качества агломерата.

\section{Выводы}

Проблема обеспечения рационального распределения шихты по крупности и по содержанию топлива по высоте слоя, загруженного на колосниковую решетку агломерационной машины, остается актуальной до настоящего времени. Поэтому практиками и учеными продолжается разработка новых методов и средств, обеспечивающих такое формирование слоя шихты на агломерационной машине, которое обеспечивает рациональное распределение гранул материала и содержащегося в нем топлива.

Предлагаемые конструктивные решения с использованием линейных разделителей шихты по крупности основаны на использовании управляемого явления естественной сегрегации загружаемого материала по крупности и по содержанию в них топлива. Реализация предложенных технологических схем позволяет обеспечить заданное распределение фракций окомкованной шихты по высоте слоя с постепенным ростом содержания топлива в верхних слоях шихты, что приводит к увеличению производительности агломерационных машин и улучшению качества выпускаемого агломерата.

\section{ЛИТЕРАТУРА}

1. Бернштейн P.С. Повышение эффективности агломерации / P.С. Берштейн. - М.: Металлургия, 1979. - 144 с.

2. Вегман Е.Ф. Теория и технология агломерации / Е.Ф. Вегман. - М.: Металлургия, 1974. - 288 с.

3. Мартыненко В.А., Производство агломерата: технология, оборудование, организация рабочего места // В.А. Мартыненко, А.С. Кухарь. - М.: Металлургия, 1985. - 75 с.

4. Новак С.Б. Теория и практика управления аглопроцессом / С.Б. Новак, Н.И. Гармаш, В.А. Мартыненко, А.В. Мартыненко / Под редакцией В.А. Мартыненко. - Кривой Рог, 2006. - 222 с.

5. Базилевич С.В. Работы по совершенствованию процессов окомкования железорудных материалов / С.В. Базилевич // Бюллетень черной металлургии. - М. - 1972. - №4. - С. 3-6.

6. Базилевич С.В. Интенсификация агломерационного процесса и улучшение качества агломерата при спекании тонкоизмельченных концентратов / С.В. Базилевич // Бюллетень черной металлургии. - М. - 1975. - №24. - С. 16-23.

7. Бернштейн Р.С. Пути улучшения качества агломерата / Р.С. Бернштейн, С.В. Базилевич // Металлургия, 1975. - №4. - С. 10-13.

8. Пузаков В.П. Причины неравномерного химического и минералогического состава агломерата по высоте слоя / В.П. Пузаков, А.М. Ли, С.Х. Масыбулин и др. // Металлургическая и горная промышленность. - 1968. - №4. - С. 8-12.

9. Старшинов Б.К. Зависимость металлургических свойств агломерата от способа загрузки шихты на спекательные тележки концентратов / Б.К. Старшинов, А.Е. Лебедев, З.А. Михальчук и др. // Бюллетень черной металлургии. - М. -1972. - №11. - С. 36-37.

10. Ефименко Г.Г. Распределение углерода при окомковании агломерационной шихты / Г.Г. Ефименко, С.П. Ефимов // Известия вузов. Черная металлургия. 
11. Готовцев А.А. Оценка сегрегации агломерационной шихты / А.А. Готовцев, И.М. Сальников, В.Н. Тихонов // Теоретические основы и технология подготовки металлургического сырья к доменной плавке: Респуб. научно-техническая конференция. - Днепропетровск, 1980. - С. 29-30.

12. Губанов В.И. Справочник рабочего-агломератчика / В.И. Губанов, А.М. Цейтлин. Челябинск: Металлургия, 1987. - 207 с.

13. А.с. 964400 СССР, МКИ F27 В 21/06. Конвейерная агломерационная машина / Ю.С. Рудь, В.Г. Кучер. - 3008275 / 22-02; заявл. 24.11.80; опубл. 07.10.1987, Бюл. 37.

14. Патент 109837 Україна / МПК B22F 3/00. Спосіб спікання шихти на агломераційних машинах / Ю.С. Рудь, В.Г. Кучер. - u 2016 02389; заявл. 12.03.2016; опубл. 19.09.82016, Бюл. №17.

15. Коршиков Г.В. Формирование структуры слоя при однослойной и двухслойной загрузке шихты на аглоленту / Г.В. Коршиков, М.А. Хайков, А.В. Буев. и др. // Теплотехника и газодинамика агломерационного процесса. - К.: Наукова думка, 1983. - С. 22-25.

16. По В.И. Анализ методов исследования сегрегационных процессов в агломерационной шихте / В.И. По, М.Ю. Пазюк, Ю.М. Пазюк, М.А. Безверхая. www.zgia.zp.ua/gazeta/METALURG_20_1.pdf.

17. А. C. №304291 SU. Устройство для разделения фракционного состава шихты / А.Л. Матов, Л.Р. Мигуцкий, В.Г. Кучер. - №14198337 / 22-2; опублик. 11.06.1971, Бюл. №19.

18. Патент 109978 Україна, МПК B65G 65/00 F 27 В 21/00. Спосіб завантаження шихти на колосникові грати агломераційної машини / Ю.С. Рудь, В.Г. Кучер. - u 2016 00997; заявл. 08.02.20016; опубл. 26.09.82016, Бюл.№18.

\section{REFERENCES}

1. Bernshteyn R.S. Povyishenie effektivnosti aglomeratsii / R.S. Bershteyn. - M.: Metallurgiya, 1979. $144 \mathrm{~s}$.

2. Vegman E.F. Teoriya i tehnologiya aglomeratsii / E.F. Vegman. - M.: Metallurgiya, 1974. - $288 \mathrm{~s}$.

3. Martyinenko V.A., Proizvodstvo aglomerata: tehnologiya, oborudovanie, organizatsiya rabochego mesta // V.A. Martyinenko, A.S. Kuhar. - M.: Metallurgiya, 1985. - 75 s.

4. Novak S.B. Teoriya i praktika upravleniya agloprotsessom / S.B. Novak, N.I. Garmash, V.A. Martyinenko, A.V. Martyinenko / Pod redaktsiey V.A. Martyinenko. - Krivoy Rog, 2006. - 222 s.

5. Bazilevich S.V. Rabotyi po sovershenstvovaniyu protsessov okomkovaniya zhelezorudnyih materialov / S.V. Bazilevich // Byulleten chernoy metallurgii. - M. - 1972. - \#4. - S. 3-6.

6. Bazilevich S.V. Intensifikatsiya aglomeratsionnogo protsessa i uluchshenie kachestva aglomerata pri spekanii tonkoizmelchennyih kontsentratov / S.V. Bazilevich // Byulleten chernoy metallurgii. M. - 1975. - \#24. - S. 16-23.

7. Bernshteyn R.S. Puti uluchsheniya kachestva aglomerata / R.S. Bernshteyn, S.V. Bazilevich // Metallurgiya, 1975. - \#4. - S. 10-13.

8. Puzakov V.P. Prichinyi neravnomernogo himicheskogo i mineralogicheskogo sostava aglomerata po vyisote sloya / V.P. Puzakov, A.M. Li, S.H. Masyibulin i dr. // Metallurgicheskaya i gornaya promyishlennost. - 1968. - \#4. - S. 8-12.

9. Starshinov B.K. Zavisimost metallurgicheskih svoystv aglomerata ot sposoba zagruzki shihtyi na spekatelnyie telezhki kontsentratov / B.K. Starshinov, A.E. Lebedev, Z.A. Mihalchuk i dr. // Byulleten chernoy metallurgii. - M. -1972. - \#11. - S. 36-37.

10. Efimenko G.G. Raspredelenie ugleroda pri okomkovanii aglomeratsionnoy shihtyi /

G.G. Efimenko, S.P. Efimov // Izvestiya vuzov. Chernaya metallurgiya. 
11. Gotovtsev A.A. Otsenka segregatsii aglomeratsionnoy shihtyi / A.A. Gotovtsev, I.M. Salnikov, V.N. Tihonov // Teoreticheskie osnovyi i tehnologiya podgotovki metallurgicheskogo syirya $\mathrm{k}$ domennoy plavke: Respub. nauchno-tehnicheskaya konferentsiya. - Dnepropetrovsk, 1980. - S. 29-30.

12. Gubanov V.I. Spravochnik rabochego-aglomeratchika / V.I. Gubanov, A.M. Tseytlin. Chelyabinsk: Metallurgiya, 1987. - 207 s.

13. A.s. 964400 SSSR, MKI F27 B 21/06. Konveyernaya aglomeratsionnaya mashina / Yu.S. Rud, V.G. Kucher. - 3008275 / 22-02; zayavl. 24.11.80; opubl. 07.10.1987, Byul. 37.

14. Patent 109837 UkraYina / MPK B22F 3/00. SposIb spIkannya shihti na aglomeratsIynih mashinah / Yu.S. Rud, V.G. Kucher. - u 2016 02389; zayavl. 12.03.2016; opubl. 19.09.82016, Byul. \#17.

15. Korshikov G.V. Formirovanie strukturyi sloya pri odnosloynoy i dvuhsloynoy zagruzke shihtyi na aglolentu / G.V. Korshikov, M.A. Haykov, A.V. Buev. i dr. // Teplotehnika i gazodinamika aglomeratsionnogo protsessa. - K.: Naukova dumka, 1983. - S. 22-25.

16. Po V.I. Analiz metodov issledovaniya segregatsionnyih protsessov v aglomeratsionnoy shihte / V.I. Po, M.Yu. Pazyuk, Yu.M. Pazyuk, M.A. Bezverhaya. www.zgia.zp.ua/gazeta/METALURG_20_1.pdf.

17. A. S. \#304291 SU. Ustroystvo dlya razdeleniya fraktsionnogo sostava shihtyi / A.L. Matov, L.R. Migutskiy, V.G. Kucher. - \#14198337 / 22-2; opublik. 11.06.1971, Byul. \#19.

18. Patent 109978 UkraYina, MPK B65G 65/00 F 27 V 21/00. SposIb zavantazhennya shihti na kolosnikovI grati aglomeratsIynoYi mashini / Yu.S. Rud, V.G. Kucher. - u 2016 00997; zayavl. 08.02.20016; opubl. 26.09.82016, Byul.\#18.

Received 17.01.18

\section{NEW DIRECTION IN DEVELOPMENT OF METHODS AND MEANS OF SHIELD LAYER FORMING ON AGGLOMERATION MACHINE}

Drum loaders that are used on sintering machines for loading of charge on a grate from furnace-bars does not provide the receipt of rational segregation of charge on the height of layer. Attempts to bring down negative influence of the segregation of material got here by piling on the grate of sintering machines two or the more layers of charge did not give the expected results. A question of achievement of the set distribution of material of charge on largeness on the height of layer due to the guided segregation of the loaded material still is an actual scientific and practical task. The analysis of efficiency of the known methods and facilities of forming of layer of charge is executed at her piling on the furnace-bar grate of sintering machines. It is shown that one of the most perspective directions of forming of layer of charge is a management by the process of segregation of granular charge on the height of layer depending on her largeness and maintenance in it fuels. For the division of charge there can one of types of technological equipment be linear delimiters on factious composition. Realization of the offered flow sheets with the use of linear delimiters provides the set distribution of factions of granular charge on the height of layer with the gradual height of maintenance of fuel in the epiphyses of charge, what the productivity of sintering machines allows to increase and to improve quality of the produced agglomerate.

Keywords: agglomeration machine, agglomerate, charge segregation, linear separator, productivity, quality of agglomerate.

\section{НОВИЙ НАПРЯМОК У РОЗРОБЦІ МЕТОДІВ І ЗАСОБІВ ФОРМУВАННЯ ШАРУ ШИХТИ НА АГЛОМЕРАЦІЙНІЙ МАШИНІ}

Барабанні живильники, які застосовуються на агломераційних машинах для завантаження шихти на колосникові грати, не забезпечують отримання раціональної сегрегації шихти по висоті шару. Спроби зменшити негативний вплив отриманої при цьому сегрегації матеріалу шляхом укладання на грати агломераційних машин двох або більше шарів шихти не дало очікуваних результатів. Питання досягнення заданого розподілу матеріалу шихти за крупністю по висоті шару за рахунок керованої сегрегації завантаженого матеріалу як 
i раніше $є$ актуальним науковим і практичним завданням. Виконаний аналіз ефективності відомих методів і засобів формування шару шихти при ï укладанні на колосникові грати агломераційних машин. Показано, що одним з найбільш перспективних напрямів формування шару шихти $€$ управління процесом сегрегації гранульованої шихти по висоті шару залежно від iï крупності та змісту в ній палива. Одним з видів технологічного устаткування для розділення шихти за фракційним складом можуть бути лінійні роздільники. Реалізація запропонованих технологічних схем 3 використанням лінійних роздільників забезпечує заданий розподіл фракцій гранульованої шихти по висоті шару з поступовим зростанням вмісту палива у верхніх шарах шихти, що дозволяє збільшити продуктивність агломераційних машин і покращити якість агломерату, що випускається.

Ключові слова: агломераційна машина, агломерат, сегрегація шихти, лінійний роздільник, продуктивність, якість агломерату.

Рудь Юрій Савелійович - д.т.н, професор, кафедра прикладної механіки та загальноінженерних дисциплін, ДВНЗ «Криворізький національний університет».

Rud Yuriy -doctor of technical sciences, professor, department of applied mechanics and general engineering disciplines, State University "Krivoy Rog National University".

Кучер Василий Григорович - к.т.н., с.н.с.

Kucher Vasily -Ph.D., Ph.D.

Білоножко Вікторія Юріївна - старший викладач, кафедра прикладної механіки та загальноінженерних дисциплін, ДВНЗ «Криворізький національний університет».

Bilonozhko Victoria - senior lecturer, the Department of Applied Mechanics and General Engineering, and the Krivorozhsky National University. 